\title{
ІСТОРІЯ ПЕДАГОГІКИ
}

\author{
УДК 373.2/.3.091.4Борович \\ DOI https://doi.org/10.32840/1992-5786.2021.75-2.1
}

Я. В. Матюшинець

аспірантка, викладач кафедри педагогіки та психології Київського університету імені Бориса Грінченка

\section{ПРАКТИЧНІ АСПЕКТИ РОЗВИВАЛЬНОГО СЕРЕДОВИЩА ДИТЯЧОГО КЛУБУ ЗА МАТЕРІАЛАМИ КНИГИ Б. БОРОВИЧА «ДИТЯЧИЙ КЛУБ (ІСТОРІЯ ОДНОГО ДОСВІДУ)» (1919)}

У статті висвітлено розвивальний аспект середовища дитячого клубу для дітей дошкільного та молодшого шкільного віку, що фрункціонували на теренах України на початку XX століття (за матеріалами книги «Дитячий клуб (Історія одного досвіду)» (1919р.)) Бориса Боровича. Охарактеризовано суспільне та розвивальне значення дитячих клубів для дітей дошкільного та молодшого шкільного віку, з сімей бідних верств населення.

Проаналізовано вплив умов середовищ дитячих клубів на всебічний розвиток дітей дошкільного та молодшого шкільного віку. Висвітлено фрорми і методи, що застосовувались педагогами під час роботи з дітьми дошкільного та молодшого шкільного віку у розвивальному середовищі дитячого клубу, для реалізації самодіяльності дітей (ігри-заняття, ігри-розваги) та розширення їхніх знань про навколишнє середовище (бесіди, екскурсії, прогулянки). За результатами вивчення досвіду діяльності дитячого клубу, що діяв в м. Одеса, розкрито особливості організації розвивального процесу, розподілу дітей дошкільного та молодшого шкільного віку на групи та змісту роботи в групах.

Окреслено підходи до облаштування розвивального середовища дитячого клубу та розподілу його на предметні зони. Виявлено, що у предметно-розвивальному середовищі дитячого клубу педагоги значну увагу приділяли підбору функціонального інвентаря для групових і самостійних ігор дітей дошкільного та молодшого шкільного віку. З'ясовано, що дитячі клуби створювалися з урахуванням творчих нахилів та індивідуальних особливостей кожного вихованця. Вивчення матеріалів про діяльність дитячого клубу засвідчило, що створення сприятливої атмосфери в середовищі дитячого клубу спонукало дітей дошкільного та молодшого шкільного віку до прояву ініціативності, стійкості, мужності, самодіяльності та співпраці в умовах групи дітей (різного віку і статі). Окрім того, висвітлено значення дитячого колективу в розвивальному середовищі дитячого клубу для формування комунікативних умінь.

Також у статті представлено досвід створення у середовищі дитячого клубу бібліотеки і читальні для прищеплення у дітей дошкільного та молодшого шкільного віку любові до читання. 3 огляду на це проаналізовано і висвітлено поширені методи читання, які застосовували педагоги в розвивальному середовищі дитячих клубів (читання «з чарівним ліхтарем», читання з демонстрацією картин, читання-бесіди, самостійне читання).

Ключові слова: розвивальне середовище, дитячий клуб, соціальне довкілля, діти дошкільного віку, діти молодшого шкільного віку, Б. Борович.

Постановка проблеми. Модернізація дошкільної та початкової освіти в Україні в руслі Концепції «Нова українська школа»(2016) актуалізує вивчення історико-педагогічних здобутків попередніх періодів щодо висвітлення досвіду функціонування розвивальних середовищ для дітей дошкільного та молодшого шкільного віку. У перебігу змін суспільних запитів і батьків трансформується мета та завдання дошкільної та початкової освіти. Законом України «Про освіту» (2017) передбачено фрормування всебічно розвиненої особистості з урахуванням ії̈ розумового рівня, фрізичних навичок і творчих здібностей [2].
Тому доцільно організоване розвивальне середовище забезпечує умови для всебічного розвитку особистості. Розвивальні середовища закладів дошкільної та початкової освіти України окрім інтелектуального розвитку особистості у вихованців мають сформувати базові загальнолюдські цінності й громадянську відповідальність для успішної реалізації їхніх життєвих компетентностей [2].

Вивчення означеної наукової проблеми дає підстави розглядати в історичній ретроспективі імперської доби розвивальні середовища дитячих клубів ,що доповнювали в 1910-і роки палітру дитячих садків і народних шкіл на теренах 
Центральної України. 3 огляду на значущість розвивальних середовищ для всебічного розвитку дітей дошкільного та молодшого шкільного віку актуалізується необхідність історико-педагогічних студій, для виокремлення провідних педагогічних ідей діяльності дитячих клубів, що створювались із метою забезпечення збереження здоров'я дітей в умовах складних економічних ,соціальних зрушень і підготовки їх до школи.

Аналіз останніх досліджень і публікацій 3 означеної проблематики показав, що окремі аспекти фуннціонування розвивальних середовищ дитячих клубів $€$ предметом пошуків сучасних українських науковців і вчених. Так, окремі аспекти реалізації ідей трудового виховання в розвивальних середовищах дошкільних закладів у 1920-х роках висвітлено (Г. Іванюк, Є. Антипін ), зокрема і дитячих клубів, що функціонували в радянську добу (1919-1928); особливості становлення та розвитку дозвілля дітей (20-ті рp. XX ст.) в Україні (І. Петрова); заклади позашкільної освіти як центри творчості дітей дошкільного та молодшого шкільного віку (з 1919 р.) на теренах України (Т. Сорока); здійснено аналіз розвитку клубів дозвілля школярів у хронологічних межах 1920-1980 років (Т. Яцула).

За результатами вивчення праць сучасних науковців нами 3'ясовано, що незважаючи на значну кількість проаналізованих джерел з окремих питань означеної проблематики, нами не виявлено цілісне дослідження щодо практики функціонування розвивальних середовищ клубів для дітей дошкільного та молодшого шкільного віку в означених територіальних і хронологічних межах.

3 огляду на значний інтерес науковців і фахівців із дошкільної та початкової освіти до практичних доробків педагогів минулих періодів, пошук шляхів удосконалення освітньої ґалузі, актуалізується студіювання матеріалу ,висвітленого у книзі Б. Боровича «Дитячий клуб (Історія одного досвіду)» (1919 р.), з метою виокремлення корисних практик, що можуть становити цінність.

Мета статті - проаналізувати педагогічні практики Б. Боровича щодо функціонування середовища дитячого клубу, висвітлені на сторінках авторського доробку «Дитячий клуб (Історія одного досвіду)» (1919); виокремити практики, що можуть становити інтерес для наукової та фрахової спільнот.

Виклад основного матеріалу. Зважаючи на актуалізацію ідей про розвивальні середовища дитячих клубів для дітей, цікавим $є$ досвід діяльності дитячого клубу, висвітлений у книзі Бориса Боровича «Дитячий клуб. Історія одного досвіду» (1919) [1]. У праці автором розлого проаналізовано досвід діяльності дитячого клубу та його соціальне значення, окрім того, перераховано труднощі, які виникали під час роботи з вихованцями в середовищі цієї дитячої установи.

Борович Борис Осипович (Фінкельштейн) український педагог, бібліотекознавець, книгознавець і бібліограф. Борис Осипович народився у місті Одеса 19 листопада 1883 року. За антикласові (антирадянські) погляди був репресований і розстріляний 23 вересня 1938 року (реабілітований 1993 року, посмертно) [6]. На початку XX століття здійснював педагогічну діяльність у сфері позашкільної освіти. Окрім того, був засновником робітничих клубів та дитячих вихованих закладів. Так, під керівництвом Бориса Боровича влітку 1912 року в Одесі було створено дитячий клуб під назвою «Дитячий будинок». Був керівником Харківської культурно-просвітної організації «Труд» (1917-1927 рр.). У творчому доробку педагога налічується велика кількість праць присвячених бібліотечній справі, культурно-просвітницьких питань та самоосвіти [6].

Зважаючи на соціально-економічні збурення в роки першої світової війни, революційні зрушення ,національно-визвольні змагання, що відбувався на теренах тогочасної України (початок XX століття), великого значення для розвитку особистості дитини відводили середовищу. Педагогічні спільноти переймалися дітьми, які перебуваючи в несприятливих моральних і матеріальних умовах в середовищі сім'ї та на вулиці, безпосередньо накопичують негативні якості, вдаються до хуліганства, крадіжок тощо. Тому, для попередження негативних впливів соціального середовища, необхідно створювати дитячі клуби, середовище яких спрямоване на всебічний розвиток дітей молодшого шкільного віку й підготовку їх до життя у дорослому колективі $[1$, с. 3].

Зважаючи на запити суспільства та широке розповсюдження ідеї вільного виховання, на початку XX століття, було створено товариство піклування за дітьми, що опікувалося вихованням дітей із бідних верств населення. Так, товариством було вирішено організувати доступний дитячий клуб для дітей 7-14 років, для дітей пропонувалися цікаві заняття, розваги й всебічний розвиток з урахуванням мети та завдань громадянського виховання. Окрім того, середовище дитячого клубу забезпечувало сприятливу атмосферу, що спонукала дітей до ініціативності, стійкості, мужності, самодіяльності та співпраці в колективі [1, с. 5].

Так, відкриття дитячого клубу 3 назвою «Дитячий будинок» відбулося влітку 1912 року в місті Одеса. Приміщення, у якому працював дитячий клуб розташовувалося в одній просторій кімнаті з шафрою для зберігання роздаткового матеріалу, двома столами і лавками. Окрім того, біля дитячого клубу було велике подвір'я, яке слугувало місцем для проведення ігор і занять із відвідувачами. Для успішного проведення занять 
з дітьми було закуплено велику кількість білого і кольорового паперу і картону, ножиці, канцелярські ножі, олівці і кольорові фарби, нитки, голки для шиття, декілька метрів дешевого полотна [1, c. 14].

На початку діяльності дитячого клубу, предметно-ігрове середовище вміщувало невелику кількість матеріалів: зоологічного і цифрове лото, шашки, м'ячі, скакалки, дитячий більярд, крокет тощо. Окрім ігор, керівником дитячого клубу було заплановано проводити з відвідувачами заняття з ліплення, малювання і аплікації, вирізання по дереву, шиття, вишивання і в'язання [1, с. 14].

Дитячий клуб став визначним місцем, а на його відкриття прийшло багато охочих. Здебільшого це були діти 2-3-х років зі своїми старшими сестрами, школярі 10-13-и років і підлітки до 15-и років, що закінчили народну школу [1, с. 15].

Загалом, за декілька днів керівниками дитячого клубу було нараховано більше 200 відвідувачів різного віку і соціальної належності (дітей з сімей трудового класу, аристократії, торговців і ремісників) [1, с. 27]. Основним принципом діяльності дитячого клубу «Дитячий будинок» визначенодоступність для усіх дітей не залежно від їхньої класового походження, віросповідання і статі [1, c. 32].

У перший день роботи установи дітям було надано можливість самостійно ознайомитися 3 предметно-ігровим середовищем, виявити власну ініціативу та адаптуватися у нових умовах. Зокрема, керівники в перший день діяльності дитячого клубу грали роль так званих «спостерігачів», які не втручалися у діяльність дітей, а лише за потреби могли допомогти у вирішенні конфліктних ситуацій [1, с. 20-26].

Згодом педагогами дитячого клубу було введено заняття з малювання, ліплення і аплікації, рельєфне вирізання по дереву (для хлопців), шиття, вишивання і в'язання (для дівчат) під керівництвом дорослих. Для проведення занять кожного виду у кімнаті було розміщено столи 3 відповідними матеріалами. Таким чином, дитина могла собі самостійно обрати цікавий для неї вид діяльності. Цікавим $є$ те, що в разі того, якщо дитині набридло виконувати обраний раніше вид діяльності, вона могла перейти до іншого столу і приєднатися до групи яка виконувала іншу роботу [1, с. 26-27].

Так, у середовищі дитячого клубу переважна кількість занять була з ручної праці (ліплення, малювання, витинання, розфарбовування тощо) задля розвитку творчості, фантазії та самодіяльності дітей [1, с. 36-40]. Окрім ручної праці, в дитячих клубах широко впроваджувалися ігри, екскурсії та прогулянки. Так, екскурсії займали чільне у формуванні знань дітей про навколишній світ. Зокрема, екскурсії до моря, на пасіку, за місто проводилися декілька разів з групами вихованців, розподіленими за віком (з огляду на те, що дитячий клуб функціонував в Одесі, то екскурсії до моря здійснювалися досить часто, і дуже подобалися вихованцям). Також вагоме місце у розвивальному середовищі дитячого клубу займали прогулянки в природне довкілля. Колективні прогулянки проводяться для групи дітей задля відпочинку та психічного розвантаження. На прогулянках і екскурсіях діти збирали різний матеріал для виготовлення виробів для «клубного музею». Вихованці намагалися знайти якомога більше цікавих знахідок природних матеріалів, із яких можна було створити різні колекції. Така діяльність для дітей була дуже цікавою і результативною [1, с. 43]. Екскурсії і прогулянки супроводжувалися розповідями педагога про визначні місця, явища природи тощо.

Також для всебічного розвитку вихованців два рази на місяць організовувалися дитячі кіносеанси, за сприяння власника кінотеатру (безкоштовний вхід для відвідувачів дитячого клубу два рази на місяць). Під час кіносеансів дітям демонструвалися фото з різних країн світу, що висвітлювали побут народів, космічні картини. Але така ініціатива швидко припинила своє існування через недотримання низки педагогічних вимог та цензури дитячих кінофільмів [1, с. 47].

Зважаючи на суперечливі факти кінематографом, було вирішено приділити більшу увагу іграм і розвагам для виховання дітей у середовищі клубу. Також особливої уваги педагоги дитячого клубу приділяли іграм як засобу навчання дітей. Під час ігор вихованці без зусиль накопичують знання, усвідомлюють нові поняття та категорії. Але дещо інший погляд педагогів на ігри-заняття для всебічного розвитку дітей. За переконаннями педагогів, ігри-заняття не можуть повністю задовольнити запити і бажання дитини. Адже окрім навчальної і виховної мети ігор, вони мають реалізувати ігровий інтерес дитини. Зважаючи на це, ігри-розваги забезпечують відпочинок і розвантаження від навчальної діяльності [1, с. 47-48].

Окремим напрямом роботи з дітьми в середовищі дитячого клубу були колективні читання. Перші спроби провести читання з «чарівним ліхтарем» були не досить успішними. Перебуваючи в темноті діти були неуважними, починали бешкетувати і зривати процес читання [1, с. 91-92].

Наступною спробою було читання з демонстрацією картин. Досвід проведення такого читання мав дещо більший успіх, але дітям було досить не просто швидко переключатися дітям від слухання до споглядання і осмислення отриманої інформації [1, с. 92-93].

Поступово зросла роль книги в середовищі дитячого клубу. Керівником дитячого клубу було підібрано декілька цікавих за змістом книжок, що 
відповідали віку дітей. Спочатку дитячий інтерес до книжок був не стійкий, діти брали книжки, переглядали їх і повертали назад. Але коли інтерес підвищувався, діти самі запропонували педагогу читати оповідання вголос. В основному такі читання оповідань зацікавлювали дітей від 10-и до 14- років. Це пояснювалося тим, що у дітей молодшого віку ще не сформувалась посидючість і терплячість. Для читання відбиралися казки і оповідання, наповнені життєвою правдивістю, моральністю, ціннісними орієнтаціями та спонукати до формування цілісної особистості вихованця. Окрім того, усі твори, що читаються дітям мали відображати героя яскравою, сильною і творчою індивідуальністю, що спонукатиме вихованців до активної діяльності та викликатиме позитивні враження [1, с. 94-96].

Але досягти гарного результату від читання книжок дітям можна лише 3 дотриманням правильної техніки читання. Педагогу необхідно уміти володіти власним голосом, підбирати темп, ритм, виразність і висоту голосу відповідно до тематики оповідання. Також залежно від віку дитячого колективу - скорочувати твір і час читання, замінювати незнайомі слова часто вживаними й пропускати речення, що відображають сцени жорстокості чи насилля. Також педагогу під час колективного читання рекомендовано закривати ілюстрації, що знаходяться в книзі, адже нерідко вихованцям стає цікаво, що зображено на малюнку через, що захопливий процес слухання швидко завершується спогляданням картинок [1, с. 98].

Ще однією цікавою технікою, якою послуговувались педагоги дитячого клубу, є читання-бесіди. Така техніка колективного читання проводилася за потребою. В разі, якщо педагог бачив, що у дітей $\epsilon$ потреба продовжити дискусію на основі прочитаного, то вихованцям давалася змогу висловлювати власні оцінки щодо ситуації, відповідно до сюжету твору [1, с. 109].

Зважаючи на широкий інтерес вихованців до колективного читання, виникла потреба у створенні клубної бібліотеки і читальні, де діти могли самостійно обирати і читати книжки [1, с. 99]. Так, за 3-4 місяця в бібліотеці дитячого клубу налічувалося 900 книжок. Усі книжки ретельно відбиралися 3 урахуванням педагогічних вимог до дитячих книжок [1, с. 115]. 3 огляду на ц, книжки, що зберігалися у бібліотеці, були розподілені на п'ять вікових груп: для дітей молодшого віку, молодшого-середнього; середнього; середнього-старшого і старшого (13-15 років) [1, с. 116]. Цікаво, що дітей дошкільного віку, які ще не вміли читати (3-5 років), також приваблювало середовище бібліотеки дитячого клубу [1, с. 120]. Отже, для прищеплення бережливості до книги та любові до читання в умовах розвивального середовища дитячого клубу було облаштовано клубну бібліо- теку і читальню, де зберігалася велика кількість педагогічно доцільної дитячої літератури для дітей дошкільного та молодшого шкільного віку.

Висновки i пропозиції. За результатами вивчення джерел щодо практик фрункціонування середовища дитячого клубу для дітей дошкільного та молодшого шкільного віку виявлено, що матеріали книги «Дитячий клуб (Історія одного досвіду)» (1919р.) Бориса Боровича становили вагомий практичний внесок у створення та функціонування розвивальних середовищ дитячих клубів.

Досліджено, що за період роботи дитячого клубу (8-9 місяців) було створено сприятливе середовище для всебічного розвитку дітей різного віку, враховано індивідуальність кожного вихованця. За час роботи дитячої установи було більше 500 відвідувачів різного віку (за попередніми даними, перед відкриттям дитячого клубу було заплановано приймати дітей від 7 до 14 років, але зважаючи на соціально несприятливе становище сімей, у яких виховувались діти, вік відвідувачів знизився до 3-х років). Предметно-розвивальне середовище дитячого клубу сприяло реалізації оздоровчої та здоров'я збережувальної функцій. Окрім того, задля забезпечення інтересів дітей педагогами було створено зонування різних видів діяльності, різноманітні екскурсії сприяли фоормування знань про природу, культурне та соціальне довкілля. Зважаючи на вивищення ролі читання у житті дітей, у середовищі дитячого клубу було створено бібліотеку і читальню для вихованців. За сприянням різних благодійників та держави бібліотека дитячого клубу поповнювалася педагогічно доцільними для дитячого колективу книжками. Також у середовищі дитячого клубу кожного дня проводилися ігри-заняття та ігри-розваги. Так, перші були спрямовані на навчання і розвиток дитини, другі - для психічного розвантаження дитячого організму та розваги.

3 огляду на широке наповнення розвивального середовища дитячого клубу різними засобами навчання, виховання та розвитку дітей можемо зробити висновок, що такий вид установ для дітей позитивно впливав на особистісне становлення вихованців, творчу реалізацію власних задумів, самодіяльності й уміння працювати в колективі.

Отже, висвітлені ідеї щодо практичних аспектів функціонування середовища дитячих клубів за матеріалами книги «Дитячий клуб (Історія одного досвіду)» (1919 р.) Бориса Боровича можуть бути предметом історико-педагогічних студіювань, а результати дослідження не вичерпують усіх питань означеної проблематики. Нині досвід створення та функціонування розвивальних середовищ дитячих клубів на теренах України становлять теоретичний і практичний інтерес, а окремі ідеї можуть бути впроваджені в сучасні заклади дошкільної і початкової освіти. 


\section{Список використаної літератури:}

1. Борович. Детский клуб (История одного опыта). Харьков : Культурно-просветительная организация «Труд», 1919. IV, 128 с.

2. Закон України «Про освіту» від 05.09.2017 № 2145-VIII. URL: https://zakon.rada.gov.ua/laws/ show/2145-19/page\#Text (дата звернення: 21.02.2021).

3. Іванюк Г.І., Антипін Є.Б. Адаптація ідей наступності трудового виховання дітей дошкільного та молодшого шкільного віку у педагогічній думці та практиці радянської доби (1919-1928). Молодий вчений. 2016. № 11. С. 436-440. URL : http://nbuv.gov.ua/UJRN/molv_2016_11_104.

4. Петрова І. Становлення та розвиток дозвілля як соціально-культурного явища в Україні: 20-ті роки XX ст. Вісник Національної академії керівних кадрів культури і мистецтв. Вид-во. Національна академія керівних кадрів культури і мистецтв. 2009. Вип. 2. С. 34-38.
5. Сорока Т.П. Позашкільна освіта: ретроспектива та виклики сьогодення. Наукові записки Тернопільського національного педагогічного університету імені Володимира Гнатюка. Серія: Педагогіка. 2016. № 1. C. 31-37. URL: http://nbuv.gov.ua/UJRN/ NZTNPU_ped_2016_1_7 (дата звернення: 21.02.2021).

6. Черевко А.О. Борович Борис Осипович / Енциклопедія Сучасної України: електронна версія [веб-сайт] / гол. редкол.: І.М. Дзюба, А.І. Жуковський, М.Г. Железняк та ін. ; НАН України, НТШ. Київ: Інститут енциклопедичних досліджень НАН України, 2004. URL: http://esu.com.ua/search_articles.php?id=37270 (дата звернення: 21.02.2021).

7. Яцула Т.В. Історико-педагогічний аналіз розвитку клубів дозвілля школярів. 3б. наук. праць. Педагогічні науки. Херсон : Вид-во ХДУ, 2005. Вип. 40. С. 370-375.

Matiushynets Ya. Practical aspects of the developing environment of the children's club, based on the book by B. Borovich "Children's club (The story of one experience)" (1919)

The article highlights the developing aspect of the children's club environment for children of preschool and primary school age who functioned in Ukraine at the beginning of the twentieth century (based on the materials of the book Children's Club (History of One Experience) (1919)) by Boris Borovich. The social and developmental importance of children's clubs for children of preschool and primary school age, from families of the poor, was described.

The influence of the environment conditions of children's clubs on the comprehensive development of children of preschool and primary school age was analyzed. The forms and methods used by teachers when working with children of preschool and primary school age in the developing environment of the children's club, for the implementation of amateur activities of children (games occupation, games-entertainment) and expanding their knowledge about the environment (conversations, excursions, walks) are covered. Based on the results of the study of the experience of the children's club operating in Odessa, the peculiarities of the organization of the developmental process, the distribution of children of preschool and primary school age into groups and the content of work in groups were revealed.

Approaches to the development environment of the children's club and its distribution to subject areas have been determined. It was revealed that in the subject-developing environment of the children's club, teachers paid considerable attention to the selection of functional equipment for group and independent games for children of preschool and primary school age. It was found out that children's clubs were created taking into account the creative inclinations and individual features of each pupil. A study of materials on the activities of the children's club showed that the creation of a favorable atmosphere among the children's club prompted children of preschool and primary school age to show initiative, resilience, courage, amateur activity and cooperation in a group of children (different ages and gender). In addition, the importance of the children's team in the developing environment of the children's club for the formation of communication skills was highlighted.

The article also presents the experience of creating a library and reading room for instilling in children of preschool and primary school age the love of reading. Given this, the common reading methods used by teachers in the developing environment of children's clubs (reading "with a magic lantern, reading with a demonstration of paintings, reading-talking, independent reading) were analyzed and illuminated.

Key words: developmental environment, children's club, the social environment, preschool children, primary school-age children, B. Borovich. 